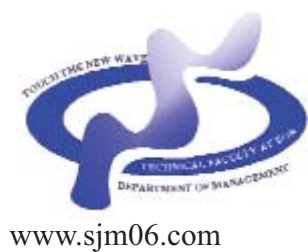

Serbian Journal of Management 10 (1) (2015) 3 - 17

\title{
FOCUS FORECASTING IN SUPPLY CHAIN: THE CASE STUDY OF FAST MOVING CONSUMER GOODS COMPANY IN SERBIA
}

\author{
Zoran Rakićevič* and Mirko Vujošević \\ Faculty of Organisational Sciences, University of Belgrade, \\ Jove Ilica 154, 11000 Belgrade, Serbia \\ (Received 05 November 2014; accepted 14 January 2015)
}

\begin{abstract}
This paper presents an application of focus forecasting in a fast moving consumer goods (FMCG) supply chain. Focus forecasting is tested in a real business case in a Serbian enterprise. The data used in the simulation refers to the historical sales of two types of FMCG with several different products. The data were collected and summarized across the whole distribution channel in the Serbian market from January 2012 to December 2013. We applied several well-known time series forecasting models using the focus forecasting approach, where for the future time period we used the method which had the best performances in the past. The focus forecasting approach mixes different standard forecasting methods on the data sets in order to find the one that was the most accurate during the past period. The accuracy of forecasting methods is defined through different measures of errors. In this paper we implemented the following forecasting models in Microsoft Excel: last period, all average, moving average, exponential smoothing with constant and variable parameter $\alpha$, exponential smoothing with trend, exponential smoothing with trend and seasonality. The main purpose was not to evaluate different forecasting methods but to show a practical application of the focus forecasting approach in a real business case.
\end{abstract}

Keywords: focus forecasting, moving average, exponential smoothing, Holt's model, Winter's model, fast moving consumer goods (FMCG)

\section{INTRODUCTION}

All issues of a supply chain planning system start from demand forecasting which serves as the basis of every planning activity
(Chen \& Blue, 2010). Fildes et al. (2009) stated that demand forecasting is the crucial aspect of a planning process in supply-chain companies. Sales forecasting forms the basis of all supply chain planning activities

\footnotetext{
* Corresponding author: zoran.rakicevic@fon.bg.ac.rs
}

DOI:10.5937/sjm10-7075 
(Chopra \& Meindl, 2007). The first step that managers must take is to forecast what customer demand will be. With adequate anticipation of sales, managers can plan the level of activities: production, capacity, inventory, transportation, distribution. Information on demand is one of the most important parts in the whole supply chain planning (Chen \& Blue, 2010) and adequate sales forecast can prevent a bullwhip effect (Ramanathan \& Muyldermans, 2010; Oyatoye \& Fabson, 2011). It can be concluded that sale forecasting is: (1) an activity of Supply Chain Management-SCM (Warren Liao \& Chang, 2010), (2) the main planning problem in SCM (Zamarripa et al., 2012) and (3) the key success factor of the SCM (Thomassey, 2010). In this paper we applied several time-series forecasting methods through the focus forecasting system. The idea was to point out the importance of successful forecasting system in supply chains and to indicate the need for development of adequate forecasting system with plenty of forecasting methods and forecast accuracy indicators.

This paper is organized as follows: Section 2 defines the term of forecasting and presents a group of forecasting methods that are based on time series. Section 3 presents and defines focus forecasting approach with measures of forecasting accuracy i.e. error, which is important element of this concept. Section 4 presents a case study on focus forecasting applied on sales of two types of FMCG; time-series forecasting methods are used on real data from practice and compared using different measures of forecasting errors. Section 4 also presents main results and discussion. Section 5 concludes the paper and discusses future research.

\section{FORECASTING METHODS}

Forecasting is a process of building assumptions and estimates about future events that are generally unknown and uncertain (Vujošević, 1997). Forecasting is the art and science of predicting future events. It implies taking historical data and projecting them into the future, using mathematical models and methods or intuition. Forecasts are used for many purposes: marketing, sales, finance/accounting, production/purchasing, and logistics (Kerkkänen et al. 2009). Numerous factors are related to the sales forecast (Chopra \& Meindl, 2007): past sales, product lead time, planned advertising or marketing efforts, state of economy, planned price discounts, competitors' actions.

Generally, forecasting methods are classified into two groups: quantitative methods and qualitative methods (Chopra \& Meindl, 2007; Vujošević, 1997; Heizer \& Render, 2011). Qualitative forecasting methods are based on experts' estimates and judgements as well as their experience. Quantitative forecasting methods use historical statistics and appropriate mathematical models to make future prediction. The most common categorisation of quantitative methods draws a distinction between projective and causal methods (Vujošević, 1997) i.e. time-series methods and associative methods (Heizer \& Render, 2011). Projective methods (time series methods) try to find rules in the data, where the forecast is a "picture" of history projected in future. Causal (associative) methods try to find and make causal relationship between variables (Vujošević, 1997). 
Time-series forecasting methods are probably the most used techniques for prediction of sales data within a supply chain (Thomassey, 2010; Davydenko \& Fildes, 2013). Time series is a collection of data that describes the values of variables during the observed period of time. Some of the statistical techniques for forecasting based on time series are (Vujošević, 1997; Chopra \& Meindl, 2007; Heizer \& Render, 2011): last period estimation, arithmetic mean, moving average, weighted moving average, exponential smoothing, Holt's model (exponential smoothing with trends), Winter's model (exponential smoothing with trend and seasonality), regression analysis.

We have presented here several most used time-series forecasting methods, with the following notations of variables and constants:

$\mathrm{D}_{\mathrm{t}}$ - demand in period $\mathrm{t}$;

$F_{t}$ - forecast for period $t$;

$\mathrm{L}_{\mathrm{t}}-$ level of forecast in period $\mathrm{t}$;

$\alpha$ - smoothing parameter for forecast demand level, $0 \leq \alpha \leq 1$;

$\beta-$ smoothing parameter for trend, $0 \leq \beta \leq 1$;

$\gamma$ - smoothing parameter for seasonality, $0 \leq \gamma \leq 1$

$\mathrm{T}_{\mathrm{t}}$-exponential smoothed trend;

$\mathrm{S}_{\mathrm{t}}$ - exponential smoothed seasonality;

FIT $_{t}$ - exponential smoothing forecast that includes trends in period $\mathrm{t}$;

FITS $_{t}$ - exponential smoothing forecast that includes trend and seasonality in period t;

$\mathrm{m}$ - number of observed periods $w$;

$\omega \mathrm{i}-$ weighted coefficient, $\omega_{\mathrm{i}}>\omega_{\mathrm{i}-1}, \omega_{\mathrm{i}}>$

$0, \omega_{\mathrm{i}}<1$;

$E_{t}-$ forecast error in period $t$;

$A_{t}-$ absolute forecast error in period $t$.

\section{Sales forecasting methods:}

Last period estimation is a simple forecasting method (strategy) that assumes that the demand in the next period will be equal to the demand in the most recent past period. This method is applied when the variations in actual values of data are small, from period to period:

$F_{t}=D_{t-1}$

Arithmetical average is a method for forecasting next period that is trying to make average of all historical sales data. Arithmetical average ignores trend and seasonality patterns.

$F_{t}=\frac{\sum_{i=1}^{t-1} D_{i}}{t-1}$

Moving average is a forecasting method that uses the average of several recent sales data for the next period sales forecast. This method follows trend patterns with a certain time delay, but seasonal patterns cannot be followed.

$F_{t}=\frac{\sum_{i=1}^{m} D_{t-i}}{m}$

If there is clear trend patterns, moving average can be upgraded with weighted coefficients. This method refers to weighted moving average:

$F_{t}=\sum_{i=m}^{t-1} \omega_{i} D_{i}$

Increasing the size of an observed period in history, this method better stabilizes fluctuations and becomes less sensitive to real changes in the data. The trends always remain in the shadow of its averageness.

Exponential smoothing is a widespread forecasting time series method within supply 
chain models (Ferbar et al., 2009). Exponential smoothing is a kind of weighted moving average, where the weights are assigned using exponential function forecast for the next period is equal to the forecast from one period earlier corrected by the weighted difference between a real demand and forecast in an earlier period.

$$
\begin{aligned}
& \mathrm{F}_{\mathrm{t}}=\mathrm{F}_{\mathrm{t}-1}+\alpha \cdot\left(\mathrm{D}_{\mathrm{t}-1}-\mathrm{F}_{\mathrm{t}-1}\right) \text { or } \\
& \mathrm{F}_{\mathrm{t}}=\alpha \cdot \mathrm{D}_{\mathrm{t}-1}+(1-\alpha) \cdot \mathrm{F}_{\mathrm{t}-1}
\end{aligned}
$$

The smoothing constant regulates the influence of historical values (Wallström \& Segerstedt, 2010). A lower value of constant $\alpha$ gives bigger significance to historical values of data. Higher value of constant $\alpha$ has an opposite effect. Recommended values for $\alpha$ constant, in literature, are between 0.1 and 0.3 (Vujošević, 1997). A basic model of exponential smoothing in long term forecasts does not take trend patterns into account. However, an exponential smoothing method can be modified for forecasting time series with a trend component.

Trend - corrected exponential smoothing, Holt's model, is a more complex model of exponential smoothing that calculates an exponential smoothing forecast and then corrects it with a positive or negative average value of a moving trend.

- Exponentially smoothed forecast of sales level:

$$
\mathrm{L}_{\mathrm{t}}=\alpha \cdot \mathrm{D}_{\mathrm{t}-1}+(1-\alpha) \cdot\left(\mathrm{L}_{\mathrm{t}-1}+\mathrm{T}_{\mathrm{t}-1}\right)
$$

- Exponentially smoothed trend:

$$
T_{t}=\beta \cdot\left(L_{t}-L_{t-1}\right)+(1-\beta) \cdot T_{t-1}
$$

- Exponentially smoothed forecast that includes trend:
$\mathrm{FIT}=\mathrm{L}_{\mathrm{t}}+\mathrm{T}_{\mathrm{t}}$

The forecast for the next period (FIT $)$ represents a sum of exponential smoothing forecast $\left(\mathrm{L}_{\mathrm{t}}\right)$ for the next period and a calculated trend for the next period $\left(T_{t}\right)$. When the value of $\beta$ parameter is high, forecasts are sensitive on recent changing in trend. Conversely, when the value of parameter $\beta$ is low, a forecast is less sensitive to a recent value and emphasis the past historical values. The value of $\beta$ can be obtained testing different values and measuring forecast error, with the help of optimizing software such as Microsoft Excel.

Trend and seasonality corrected exponential smoothing, Winter's model Seasonal variations are regular changes in the time series, up or down, related to the events that are repeated (e.g. summer or winter season, holiday season). A seasonal characteristic of variables can be identified based on increased or decreased values of demand in a certain period of year. For this purpose the seasonal indexes that represent a ratio between demands in certain periods and the average demand for a whole series are used.

Exponential smoothing method that includes trend and seasonality is:

FITS $_{t}=\left(L_{t}+T_{t}\right) \cdot S_{t}$

- Exponentially smoothed forecast of sales level:

$\mathrm{L}_{\mathrm{t}}=\alpha \cdot \frac{\mathrm{D}_{\mathrm{t}-1}}{\mathrm{~S}_{\mathrm{t}-1}}+(1-\alpha) \cdot\left(\mathrm{L}_{\mathrm{t}-1}+\mathrm{T}_{\mathrm{t}-1}\right)$

- Exponentially smoothed trend:

$T_{t}=\beta \cdot\left(L_{t}-L_{t-1}\right)+(1-\beta) \cdot T_{t-1}$ 
- Exponentially smoothed seasonality:

$\mathrm{S}_{\mathrm{t}+\mathrm{m}}=\gamma \cdot \frac{\mathrm{D}_{\mathrm{t}-1}}{\mathrm{~L}_{\mathrm{t}-1}}+(1-\gamma) \cdot \mathrm{S}_{\mathrm{t}-1}$

According to Thomassey (2010), these above presented statistical time series forecasting methods provide satisfactory results in real-life applications. All mentioned forecasting methods have different accuracy and success in sales forecasting. Chang and Lin (2010) stated: "it is very important that business and manufacturing enterprises build flexible and robust supply chain forecasting systems that allow them to reduce the negative impacts of bullwhip effect". Forecasting accuracy is a critical element of supply chain management, but, at the same time, it is the area that continues to challenge most companies (Vayvay et al., 2012).

\section{FOCUS FORECASTING}

According to Min \& Yu (2008) focus forecasting, is an expert system that identifies a simple forecasting rule-of-thumb method that worked best in the past, and uses it to make a short-term prediction for future events such as sales or customer demands. Focus forecasting often includes three steps: (1) simulate the past forecasts using a variety of forecasting rules and methods; (2) evaluate the performances of these forecasting methods with respect to forecasting errors; (3) select the forecasting method that performed best and apply it in the next period's demand. After realising sales in the next period, the sales data in the database are refreshed and the same procedure of focus forecasting is realized. This system of forecasting can be applied involving experts' opinions (Figure 1).

Focus forecasting allows application of different forecasting time-series methods and uses methods with the best accuracy, i.e. minimum forecast error (Gardner et al., 2001). Chopra and Meindl (2007) stated that using multiple forecasting methods to create a combined forecast is more effective than using any method alone. Focus forecasting can also be used for forecasting sales of different products.

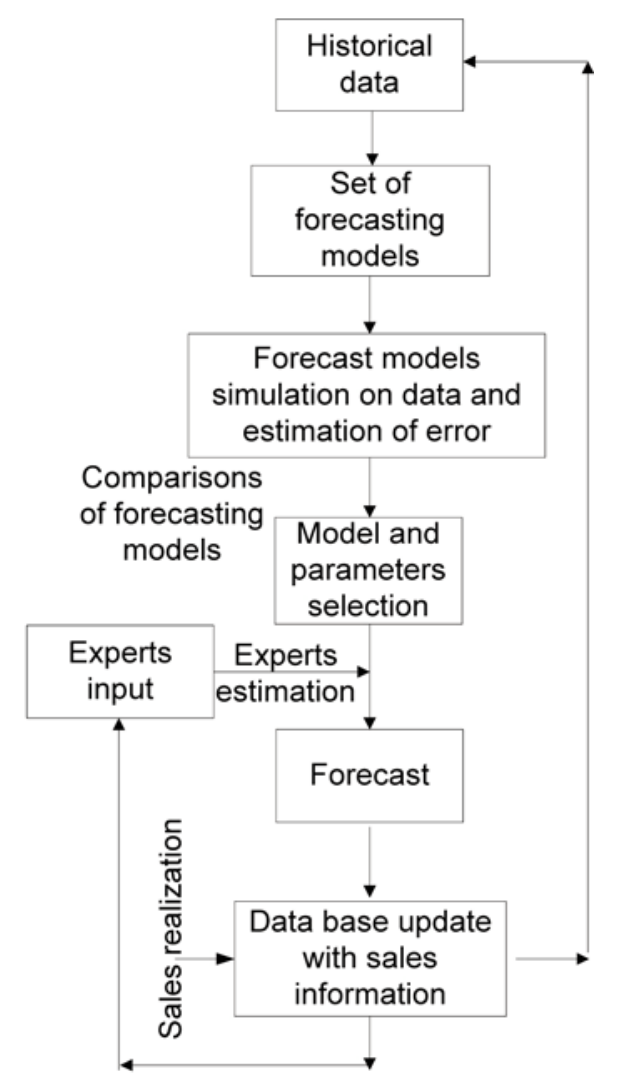

Figure 1. The diagram of focus forecasting concept, modified source (Vujošević, 1997)

Sales and demand forecasting is never $100 \%$ accurate (Warren Liao \& Chang, 2010; Oyatoye \& Fabson, 2010). The most important part in a focus forecasting system is how to measure forecast accuracy or its success. Typically, it is measured with a 
forecast error. The literature provides several different measures for forecast errors (Vujošević, 1997; Chopra \& Meindl, 2007; Kerkkänen et al. 2009; Wallström \& Segerstedt, 2010; Heizer \& Render, 2011). In general, the forecast error is defined as a difference between the forecast and actual sales. Forecasts that are larger/smaller than the actual sales are referred as over/underforecasts. According to Bratu-Simionescu (2013), some of the most popular measures of forecast accuracy are: Mean Absolute Deviation (MAD), Average of absolute deviation over all periods, Mean Absolute Percentage Error (MAPE), Mean Squared Error (MSE), Root Mean Square Error (RMSE), Cumulative error, Average error or Bias, Tracking Signal (TS). In production or service industries sales forecasting errors have significant impacts on total costs, schedule instability, lost capacity, uneconomical use of capacity, excess inventory, inventory holding cost, obsolescence, reduced margin, lost "sales" cost (Kerkkänen et al., 2009).

The forecast error in period $t$ is the difference between the actual demand in period $t$ and the forecast for period $t$ :

$\mathrm{E}_{\mathrm{t}}=\mathrm{D}_{\mathrm{t}}-\mathrm{F}_{\mathrm{t}}$

Mean absolute deviation (MAD) is a measure of total forecast errors for the model:

$$
\text { MAD }=\frac{\sum_{t=1}^{\mathrm{n}}\left|\mathrm{D}_{\mathrm{t}}-\mathrm{F}_{\mathrm{t}}\right|}{\mathrm{n}}=\frac{\sum_{\mathrm{t}=1}^{\mathrm{n}} \mathrm{A}_{\mathrm{t}}}{\mathrm{n}},
$$

where $F_{t}$ is sales forecast in period $t$ and $D_{t}$ is sales in period $t$.

Mean Squared Error (MSE) is a better measure of error than MAD, since squared function gives bigger weights to a bigger difference between real sales and forecasts. Thus, one big difference that is in absolute sum equal to several small differences is not equal in square function. The MSE can be related to the variance of the forecasting error.

$\operatorname{MSE}=\frac{\sum_{\mathrm{t}=1}^{\mathrm{n}}\left(\mathrm{D}_{\mathrm{t}}-\mathrm{F}_{\mathrm{t}}\right)^{2}}{\mathrm{n}}$

Root mean squared error (RMSE) can be used instead of MSE:

RMSE $=\sqrt{\frac{\sum_{t=1}^{n}\left(D_{t}-F_{t}\right)^{2}}{n}}$

MAD, MSE and RMSE express error volume, but do not point out at error direction, i.e. over-forecasting or underforecasting. For this purpose bias is used. Bias is a sum of differences between real sales and forecasts. Bias is also famous as a cumulated forecast error (CFE) (Wallström \& Segerstedt, 2010). CFE divided with the number of forecast periods gives average bias.

$\operatorname{Bias}=\frac{\sum_{t=1}^{n}\left(D_{t}-F_{t}\right)}{n}$

Ideal forecasting methods have zero values for MAD and bias. Positive bias shows tendency of under-forecasts, while negative bias shows tendency of overforecast (Vujošević, 1997).

Mean Absolute Percentage Error (MAPE) has advantage over MAD and MSE because its value is not dependent of product's measurement units. MAPE is an average absolute error, between forecasted values and a real sales value, presented as a percentage of demand. 
MAPE $=\frac{100 * \frac{\sum_{\mathrm{t}=1}^{\mathrm{n}}\left|\mathrm{D}_{\mathrm{t}}-\mathrm{F}_{\mathrm{t}}\right|}{\mathrm{D}_{\mathrm{t}}}}{\mathrm{n}}=\frac{100 * \frac{\sum_{\mathrm{t}=1}^{\mathrm{n}}\left|\mathrm{E}_{\mathrm{t}}\right|}{\mathrm{D}_{\mathrm{t}}}}{\mathrm{n}}$

Tracking signal (TS) is the ratio between the cumulated forecast error (CFE), i.e. bias, and the mean absolute deviation (MAD).

$\mathrm{TS}=\frac{\sum_{\mathrm{t}=1}^{\mathrm{n}}\left(\mathrm{D}_{\mathrm{t}}-\mathrm{F}_{\mathrm{t}}\right)}{\mathrm{MAD}}$

Tracking signal shows whether to revise parameters of forecasted model or not. It is a simple method that checks whether the forecast error is in the limits of tolerance, and is usually between $-3 \%$ and $+3 \%$ or $-8 \%$ and $+8 \%$, according to Vujošević (1997). Forecast errors that are within the limits of tolerance are acceptable, but if they are out of the limits, it is necessary to revise parameters of forecasting models.

Another interesting indicator that can be used for evaluation of several forecast methods is the Percentage better indicator. Percentage better is the percentage of time periods in which a certain forecast method performed better than another one (Wallström \& Segerstedt, 2010).

In the next section of the paper we applied the most usable time-series forecasting methods on a real forecasting problem in business practice in Serbia.

\section{CASE STUDY}

Many industries such as Fast Moving Consumer Goods (FMCG) seeking more accurate demand forecasting (Sayed et al. 2009). Focus on FMCG industry is not that strong from academic researchers. The main reasons are: characteristics of FMCG, poor forecast accuracy, unspecialized forecasters, unsuitable forecasting techniques, highly dynamic markets with lots of data about sales, short-term business activity planning, marketing activities that push product in sales (Chopra \& Meindel, 2007). On the other hand, successful demand forecasting have crucial important to support supply chain processes and distributor and retailer inventory planning (Huang et al. 2014). It directly affects the key performance indicators in supply chain such as: stock cover, out-of-stock, order-fill ratio, capacity utilization, and inventory levels (Sayed et al. 2009).

In this section of paper, we present a real case study from a company that produces two types of FMCG - cereals for breakfast and cereal bars for snack. FMCG are products that are characterized by: quick buying decisions of customers; short shelf life because of high consumer demands and rapid product deterioration; low cost production and low profit per item, although the profit of selling large quantities can be large. All these characteristics point out the importance and difficulties of adequate sales forecasting. Yang and Burns (2003) stated that a forecast and planning became very complex because FMCG needs to be available on customer requests and also there is a high risk of stock out or overstocking.

The Company's branch in Serbia that collaborates with an exclusive distributor uses the sales data from the distributor to make a successful system of forecasting sales, which on the other hand helps the distributor to have better supply chain management. The distributor collected the product sales data from small and big retail shops across the Serbian market from January 2012 to December 2013. The key problem consists of several questions and 
dilemmas: Which forecasting methods should be used for sales forecasting? Do we always have to use the same forecasting methods that gave good results in earlier periods? Do we have to use the same forecasting methods for all different variants of one product or not?

The idea was to use the focus forecasting methodology for sales forecasting and better management of distributor's supply chain. In this paper we considered sales data base of six different products divided into two categories: breakfast cereals (Product A to E) with one product with different variants $\left(\mathrm{B}_{1^{-}}\right.$ $\mathrm{B}_{5}$ ) and cereal bar snacks (Product F). Time series forecasting methods we used in focus forecasting were: a) Last period estimation; b) Arithmetical average of all past periods; c) Moving average for six, four, three and two months; d) Weighted moving average weighted coefficient as a variable with optimal value for error functions; e) Exponential smoothing - with constant value of coefficient $\alpha$ and optimal value for coefficient $\alpha$ optimised on error function; $f$ ) Trend corrected exponential smoothing (Holt's model) - with constant value of coefficients $\alpha$ and $\beta$ and optimal value for coefficients $\alpha$ and $\beta$ optimised on error function; g) Trend and seasonality corrected exponential smoothing (Winter's model) with constant value of coefficients $\alpha, \beta$ and $\gamma$ and with optimal value for coefficients $\alpha, \beta$ and $\gamma$.

Tables 1 to 6 present the results of focus forecasting with different forecasting methods. For evaluating results of forecasting we used three measures of error: Root Mean Squared Error (RMSE), Mean Absolute Percentage error (MAPE) and Tracking signal (TS). We omitted MSE, MAD and Bias because they were very similar to the previous ones, giving the same results. For some forecasting methods we used Microsoft Excel Solver for determining optimal values of coefficients $\alpha, \beta$ and $\gamma$, for minimum of RMSE and MAPE error functions. It is important to notice that we could also use a lot of different error functions in optimization, but it was not the subject of this paper. The simulation results of focus forecasting are presented in Tables 1 to 6. Bold values in Tables 1-6 mark the best values of forecasting error, i.e. the best applied sales forecasting methods for the specified criteria of forecasting error.

Table 1 presents the results of sales forecasting of products $\mathrm{A}$ to $\mathrm{F}$ using the

Table 1. Sales forecasting error indicators for the following methods: last period estimation; all average; moving average for six and four months

\begin{tabular}{|c|c|c|c|c|c|c|c|c|c|c|c|c|}
\hline \multirow[t]{2}{*}{ Prod. } & \multicolumn{3}{|c|}{$\begin{array}{l}\text { Last period } \\
\text { estimation }\end{array}$} & \multicolumn{3}{|c|}{ All average } & \multicolumn{3}{|c|}{$\begin{array}{c}\text { Moving average } \\
6 \text { months }\end{array}$} & \multicolumn{3}{|c|}{$\begin{array}{c}\text { Moving average } \\
4 \text { months }\end{array}$} \\
\hline & RMSE & MAPE & TS & RMSE & MAPE & TS & RMSE & MAPE & TS & RMSE & MAPE & TS \\
\hline $\mathbf{A}$ & 2760.4 & & -0.6 & 2892.9 & $37 \%$ & -7.6 & & & -4 & & & -2.8 \\
\hline $\mathbf{B}_{1}$ & 2397.4 & & -0.4 & 1955.9 & $28.3 \%$ & -6.5 & 1946.5 & & -1.2 & 1912.4 & & -0.6 \\
\hline $\mathrm{B}_{2}$ & 390.2 & $28.1 \%$ & -1.4 & 457.5 & 44.9 & -14.5 & 357.9 & 27.3 & -7.5 & 352.5 & 26. & -4.3 \\
\hline $\mathbf{B}_{3}$ & 491.5 & & -1 & & & & & & & & & -3.9 \\
\hline $\mathbf{B}_{4}$ & 490.9 & & 0.1 & & & -2 . & 50 & & 0.3 & 48 & & 0.5 \\
\hline $\mathrm{B}_{5}$ & 1391.4 & $54.2 \%$ & -1.2 & 1349.3 & 80.4 & -10.8 & 1213.4 & $57 \%$ & -5.5 & 1255.6 & & -3.5 \\
\hline$\Sigma B$ & 3135.6 & & -1.1 & 3439.3 & & -11.4 & 3020.2 & $20.31 \%$ & -4.5 & 2963.2 & & -2.8 \\
\hline $\mathrm{C}$ & 435.9 & 32.6 & -0.3 & 429.7 & $34.7 \%$ & -5.9 & 377.4 & & -3.4 & 362.4 & & -1.9 \\
\hline D & 270.3 & $37.9 \%$ & -0.4 & 189.3 & & -3.6 & 188.6 & $25.9 \%$ & -0.5 & 203.3 & $32.0 \%$ & -0.3 \\
\hline $\mathbf{E}$ & 477.8 & $38.0 \%$ & -0.8 & 442.1 & $40.1 \%$ & -2.5 & 419.2 & $36.4 \%$ & -2.5 & 392.7 & $34.1 \%$ & -2 \\
\hline $\mathbf{F}$ & 407.4 & $37.1 \%$ & 0.0 & 303.9 & $25.8 \%$ & 6.5 & 314.1 & $29.2 \%$ & 2.9 & 324.1 & $35.2 \%$ & 1.5 \\
\hline
\end{tabular}


following methods: last period estimation, all average, moving average for six and four months, analysed through three error functions (RMSE, MAPE, TS).

Table 2 presents the results of sales forecasting of products $\mathrm{A}$ to $\mathrm{F}$ using the following methods: moving average for three and two months, weighted moving average for two months optimized on RMSE and MAPE error function, analysed through three error functions (RMSE, MAPE, TS).

Table 3 presents the results of sales forecasting of products $\mathrm{A}$ to $\mathrm{F}$ using the following methods: weighted moving average for three and four months optimized on RMSE and MAPE error function, analysed through three error functions (RMSE, MAPE, TS).

Table 4 presents the results of sales forecasting of products $\mathrm{A}$ to $\mathrm{F}$ using the following methods: weighted moving average for six months optimized on RMSE and MAPE error function, exponential smoothing with constant $\alpha$ and optimized value of $\alpha$ on RMSE, analysed through three error functions (RMSE, MAPE, TS).

Table 2. Sales forecasting error indicators for the following methods: moving average for three and two months; weighted moving average for two months

\begin{tabular}{|c|c|c|c|c|c|c|c|c|c|c|c|c|}
\hline \multirow[t]{2}{*}{ Prod. } & \multicolumn{3}{|c|}{$\begin{array}{l}\text { Moving average } \\
3 \text { months }\end{array}$} & \multicolumn{3}{|c|}{$\begin{array}{c}\text { Moving average } \\
2 \text { months }\end{array}$} & \multicolumn{3}{|c|}{$\begin{array}{l}\text { W. Moving Average } \\
2 \text { opt RMSE }\end{array}$} & \multicolumn{3}{|c|}{$\begin{array}{l}\text { W. Moving Average } \\
2 \text { opt MAPE }\end{array}$} \\
\hline & RMSE & MAPE & TS & RMSE & MAPE & TS & RMSE & MAPE & TS & RMSE & MAPE & TS \\
\hline $\mathbf{A}$ & 2452.4 & $28.3 \%$ & -2 & 2705.0 & $28.6 \%$ & -1.1 & 2642.1 & $27.5 \%$ & -0.9 & 2642.7 & $27.5 \%$ & -0.9 \\
\hline $\mathbf{B}_{1}$ & 1968.5 & $27.6 \%$ & -0.1 & 2086.9 & $29.8 \%$ & -0.1 & 2086.9 & $29.8 \%$ & -0.1 & 2087.1 & $29.8 \%$ & -0.1 \\
\hline $\mathbf{B}_{2}$ & 336.4 & $25.4 \%$ & -3 & 343.5 & $26.2 \%$ & -2 & 343.4 & $26.3 \%$ & -2 & 344.9 & $26.2 \%$ & -2.1 \\
\hline $\mathbf{B}_{3}$ & 395.9 & $27.5 \%$ & -3.2 & 423.0 & $31.1 \%$ & -2 & 423 & $31.0 \%$ & -2 & 434.1 & $30.7 \%$ & -2.4 \\
\hline $\mathbf{B}_{4}$ & 489.4 & $37.7 \%$ & 0.2 & 515.7 & & 0.0 & 485.6 & & 0.1 & 490.9 & & 0.1 \\
\hline $\mathbf{B}_{5}$ & 1214.6 & $54.8 \%$ & -2.5 & 1240.9 & $52.4 \%$ & -1.6 & 1239.3 & $52.1 \%$ & -1.6 & 1250.9 & $51.1 \%$ & -1.5 \\
\hline$\Sigma \mathrm{B}$ & 2798.1 & $18.4 \%$ & -2 & 3016.7 & $18.2 \%$ & -1.4 & 2968.5 & $18.3 \%$ & -1.3 & 2980.7 & $18.2 \%$ & -1.4 \\
\hline C & 352.4 & $23.6 \%$ & -0.9 & 367.9 & $25.7 \%$ & -0.4 & 367.5 & $25.2 \%$ & -0.4 & 368.6 & $24.9 \%$ & -0.4 \\
\hline D & 209.7 & $29.8 \%$ & -0.5 & 227.5 & $31.5 \%$ & -0.3 & 227.1 & $31.5 \%$ & -0.3 & 241.2 & $31.3 \%$ & -0.2 \\
\hline $\mathbf{E}$ & 384.2 & $30.9 \%$ & -1.5 & 427.3 & $34.6 \%$ & -0.9 & 426.8 & $34.4 \%$ & -0.9 & 428.1 & $34.1 \%$ & -0.9 \\
\hline $\mathbf{F}$ & 329.3 & $32.4 \%$ & 1.4 & 362.6 & $35.2 \%$ & 0.9 & 362.5 & $35.2 \%$ & 0.8 & 384.2 & $35.2 \%$ & 0.3 \\
\hline
\end{tabular}

Table 3. Sales forecasting error indicators for the following methods: weighted moving average for three and four months

\begin{tabular}{|c|c|c|c|c|c|c|c|c|c|c|c|c|}
\hline \multirow[t]{2}{*}{ Prod. } & \multicolumn{3}{|c|}{$\begin{array}{l}\text { W. Moving Average } \\
3 \text { opt RMSE }\end{array}$} & \multicolumn{3}{|c|}{$\begin{array}{l}\text { W. Moving Average } \\
3 \text { opt MAPE }\end{array}$} & \multicolumn{3}{|c|}{$\begin{array}{l}\text { W. Moving Average } \\
4 \text { opt RMSE }\end{array}$} & \multicolumn{3}{|c|}{$\begin{array}{l}\text { W. Moving Average } \\
4 \text { opt MAPE }\end{array}$} \\
\hline & RMSE & MAPE & TS & RMSE & MAPE & TS & RMSE & MAPE & TS & RMSE & MAPE & TS \\
\hline $\mathbf{A}$ & 2358.2 & $28.1 \%$ & -2 & 2586.6 & $26.6 \%$ & -0.4 & 2402.4 & $28.1 \%$ & -2 & 2811.4 & $24.7 \%$ & 13.3 \\
\hline $\mathbf{B}_{1}$ & 1935.9 & $26.8 \%$ & -0.8 & 1948.9 & $26.6 \%$ & -0.8 & 1890.8 & $25.4 \%$ & -0.8 & 1989.2 & $27.4 \%$ & 8.2 \\
\hline $\mathbf{B}_{2}$ & 330.5 & $25.1 \%$ & -3.6 & 331.8 & $24.8 \%$ & -3.1 & 334.3 & $25.5 \%$ & -3 & 330.8 & $25.3 \%$ & 9.7 \\
\hline $\mathbf{B}_{3}$ & 394.6 & $27.4 \%$ & -3.6 & 415.4 & $26.8 \%$ & -4 & 390.3 & $27.7 \%$ & -4 & 440.7 & $22.4 \%$ & 15.0 \\
\hline $\mathbf{B}_{4}$ & 435.9 & & 0.1 & 442 & & 0.04 & 437.6 & & 0.3 & & & 9.3 \\
\hline $\mathrm{B}_{5}$ & 1204.4 & $53.7 \%$ & -2.3 & 1252.4 & $51.3 \%$ & -1.4 & 1202.3 & $53.2 \%$ & -1.9 & 1451.6 & $47.6 \%$ & 15.8 \\
\hline$\Sigma \mathbf{B}$ & 2743.5 & $18.6 \%$ & -2 & 3001.3 & $18 \%$ & -1.9 & 2783.9 & $18.6 \%$ & -1.6 & 3306.7 & $18.5 \%$ & 8.5 \\
\hline C & 339.9 & $23.2 \%$ & -1.4 & 341 & $22.9 \%$ & -1.3 & 343.2 & $23.2 \%$ & -1.9 & 382.5 & $24.4 \%$ & 9.2 \\
\hline D & 207.9 & $29.5 \%$ & -0.6 & 214.1 & $28.9 \%$ & -0.7 & 199.2 & $26.1 \%$ & -0.6 & 230.4 & $20.4 \%$ & 18.2 \\
\hline $\mathbf{E}$ & 378.0 & $31.1 \%$ & -1.8 & 394.1 & $30.9 \%$ & -2.1 & 375.7 & $31.4 \%$ & -2.2 & 451.2 & $25.4 \%$ & 17.6 \\
\hline $\mathbf{F}$ & 325.1 & $32.6 \%$ & 1.4 & 327 & $32.3 \%$ & 1.3 & 320.8 & $31.5 \%$ & 1.5 & 351.1 & $27.6 \%$ & 13.9 \\
\hline
\end{tabular}


Table 4. Sales forecasting error indicators for the following methods: weighted moving average for six months and exponential smoothing

\begin{tabular}{|c|c|c|c|c|c|c|c|c|c|c|c|c|}
\hline \multirow[t]{2}{*}{ Prod. } & \multicolumn{3}{|c|}{$\begin{array}{l}\text { W. Moving Average } \\
6 \text { opt RMSE }\end{array}$} & \multicolumn{3}{|c|}{$\begin{array}{l}\text { W. Moving Average } \\
6 \text { opt MAPE }\end{array}$} & \multicolumn{3}{|c|}{$\begin{array}{c}\text { Exponential } \\
\text { smoothing } \alpha=0.1\end{array}$} & \multicolumn{3}{|c|}{$\begin{array}{c}\text { Exponential } \\
\text { smoothing } \alpha_{\text {opt }} \text { RMSE }\end{array}$} \\
\hline & RMSE & MAPE & TS & RMSE & MAPE & TS & RMSE & MAPE & TS & RMSE & MAPE & TS \\
\hline $\mathbf{A}$ & 2363.5 & $26.5 \%$ & -3.2 & 2498.3 & $24.7 \%$ & $\begin{array}{l}-0.3 \\
\end{array}$ & 2989.3 & $32.9 \%$ & 5.1 & 2499.1 & $26.9 \%$ & -1.1 \\
\hline $\mathbf{B}_{1}$ & 1809.2 & $25.2 \%$ & -1 & 1825.9 & & -0.6 & 1913.2 & & 6 & 1912.1 & & 5 \\
\hline $\mathrm{B}_{2}$ & 333.2 & $25.6 \%$ & -2.5 & 335.3 & $25.3 \%$ & -2.9 & 399.6 & $33.9 \%$ & -5.4 & 342.6 & $26.3 \%$ & -2.6 \\
\hline $\mathbf{B}_{3}$ & 368.3 & $26.7 \%$ & -6.3 & 374.2 & $25.6 \%$ & -5.5 & 416.0 & $32.2 \%$ & -4.3 & 393.6 & $28.7 \%$ & -3.7 \\
\hline $\mathbf{B}_{4}$ & 440.7 & $33.2 \%$ & 0.7 & 451.7 & & 1 & 66.8 & & 1.9 & 463.7 & & 0.2 \\
\hline $\mathbf{B}_{5}$ & 1111.8 & $47.8 \%$ & -2.7 & 1119 & $45.3 \%$ & -1.2 & 1236.4 & $61.1 \%$ & -4.2 & 1190.2 & $2.4 \%$ & -3.1 \\
\hline$\Sigma$ B & 2662.0 & $17.8 \%$ & -0.6 & 2774 & $16.6 \%$ & -1.4 & 3190.6 & $19.6 \%$ & 0.8 & 2871.2 & $18.3 \%$ & -1.4 \\
\hline C & 339.6 & $23.1 \%$ & -1.1 & 343.4 & 22.8 & -0.3 & 452.0 & & 5.2 & 369.6 & & -0.6 \\
\hline D & 179.7 & & -1.5 & 186.6 & & -1 & & & 3.3 & 191.9 & & 5 \\
\hline E & 375.3 & $32.5 \%$ & -2 & 387.4 & $30.8 \%$ & -1 & 473.7 & $39.1 \%$ & 5.9 & 407.8 & $33.2 \%$ & -0.9 \\
\hline $\mathbf{F}$ & 305.9 & $29.6 \%$ & 2.9 & 352.6 & $26.7 \%$ & 4.6 & 322.6 & $26.0 \%$ & 12.2 & 316.6 & $27.4 \%$ & 7.6 \\
\hline
\end{tabular}

Table 5. Sales forecasting error indicators for the following methods: exponential smoothing and Holt's model

\begin{tabular}{|c|c|c|c|c|c|c|c|c|c|c|c|c|}
\hline \multirow[t]{2}{*}{ Prod. } & \multicolumn{3}{|c|}{$\begin{array}{c}\text { Exponential } \\
\text { smoothing } \alpha_{\text {opt }} \text { MAPE }\end{array}$} & \multicolumn{3}{|c|}{$\begin{array}{c}\text { Holt's model } \\
(\alpha . \beta)=(0.1 ; 0.1)\end{array}$} & \multicolumn{3}{|c|}{$\begin{array}{c}\text { Holt's model } \\
\left(\alpha_{o p t} \cdot \beta_{\text {opt }}\right) \text { RMSE }\end{array}$} & \multicolumn{3}{|c|}{$\begin{array}{c}\text { Holt's model } \\
\left(\boldsymbol{\alpha}_{\text {opt }} \cdot \beta_{\text {opt }}\right) \text { MAPE }\end{array}$} \\
\hline & RMSE & MAPE & TS & RMSE & MAPE & TS & RMSE & MAPE & TS & RMSE & MAPE & TS \\
\hline $\mathbf{A}$ & 2538.5 & $26.4 \%$ & -1 & 3312.9 & $40.4 \%$ & -3.2 & 2499.1 & $26.9 \%$ & -1.1 & 2538.5 & $26.4 \%$ & -1 \\
\hline $\mathbf{B}_{1}$ & 1938.8 & $24.5 \%$ & 9.9 & 1969.9 & $27.1 \%$ & 0.3 & 1912.1 & $25.4 \%$ & 5 & 1966.6 & $24.4 \%$ & 11.2 \\
\hline $\mathrm{B}_{2}$ & 346.5 & $26.0 \%$ & -2.1 & 422.9 & $36.5 \%$ & -7.2 & 342.6 & $26.3 \%$ & -2.6 & 421.6 & $36 \%$ & -1.7 \\
\hline $\mathrm{B}_{3}$ & 396.0 & $28.4 \%$ & -3.2 & 434.4 & $34.1 \%$ & -6.8 & 393.6 & $28.7 \%$ & -3.7 & 426.4 & $30.9 \%$ & 0.4 \\
\hline $\mathbf{B}_{4}$ & 490.9 & $33.6 \%$ & 0.1 & 489.0 & $39.0 \%$ & -1.7 & 463.7 & $35.1 \%$ & 0.2 & 469.1 & $22.3 \%$ & 12.2 \\
\hline $\mathbf{B}_{5}$ & 1204.9 & $52.2 \%$ & -2.2 & 1282.9 & $66.3 \%$ & -6.1 & 1190.2 & $52.4 \%$ & -3.1 & 1249.6 & $56.6 \%$ & 0.2 \\
\hline$\Sigma \mathrm{B}$ & 2911.3 & $18.2 \%$ & -1.3 & 3435.0 & $23.9 \%$ & -4.2 & 2871.2 & $18.3 \%$ & -1.4 & 3356.1 & $16.5 \%$ & 13.7 \\
\hline C & 370.7 & $25.3 \%$ & -0.6 & 503.6 & $39.7 \%$ & -2.8 & 369.6 & $25.5 \%$ & -0.6 & 370.7 & $25.3 \%$ & -0.6 \\
\hline D & 199.2 & $21.5 \%$ & 13.2 & 198.0 & $27.8 \%$ & -1.1 & 191.9 & $23.5 \%$ & 5 & 199.2 & $21.5 \%$ & 13.2 \\
\hline $\mathbf{E}$ & 592.2 & $36.7 \%$ & 19.2 & 516.2 & $47.3 \%$ & -1.6 & 407.8 & $33.2 \%$ & -0.9 & 592.2 & $36.7 \%$ & 19.2 \\
\hline $\mathbf{F}$ & 339.3 & $24.6 \%$ & 16.8 & 312.6 & $28.7 \%$ & 5.9 & 311.5 & $29.5 \%$ & 4.9 & 339.3 & $24.6 \%$ & 16.8 \\
\hline
\end{tabular}

Table 5 presents the results of sales forecasting of products $\mathrm{A}$ to $\mathrm{F}$ using the following methods: exponential smoothing with optimized value of $\alpha$ on MAPE, Holt's model with constant values of $\alpha, \beta$ and optimized values of $\alpha, \beta$ for RMSE and MAPE, analysed through three error functions (RMSE, MAPE, TS).

Table 6 presents the results of sales forecasting of products $A$ to $F$ using the following methods: Winter's model with constant values of $\alpha, \beta, \gamma$ and optimized value of $\alpha, \beta, \gamma$ for RMSE and MAPE, analysed through three error functions
(RMSE, MAPE, TS).

All these applied forecasting methods gave different results in forecasting product sales. As we see, there is not one forecasting method that is common for forecasting sales of every product. Furthermore, it is interesting that the best forecasting methods for summarized sales of variants of product $\mathrm{B}(\Sigma \mathrm{B})$ are not the same as forecasting methods for every product $\mathrm{B}_{1}$ to $\mathrm{B}_{5}$ separately. Also, our analysis shows that even for very similar products $\left(\mathrm{B}_{1}\right.$ to $\left.\mathrm{B}_{5}\right)$ different forecasting methods offer the best forecasting accuracy. 
Table 6. Sales forecasting error indicators for the Winter's model

\begin{tabular}{|c|c|c|c|c|c|c|c|c|c|}
\hline \multirow[t]{2}{*}{ Prod. } & \multicolumn{3}{|c|}{$\begin{array}{c}\text { Winter's model } \\
(\alpha . \beta . \gamma)=(0.01 ; 0.01 ; 0.9)\end{array}$} & \multicolumn{3}{|c|}{$\begin{array}{c}\text { Winter's model } \\
\left(\alpha_{\text {opt }} \cdot \beta_{\text {opt }} \cdot \gamma_{\text {opt }}\right) \text { RMSE }\end{array}$} & \multicolumn{3}{|c|}{$\begin{array}{c}\text { Winter's model } \\
\left(\alpha_{\text {opt }} \cdot \beta_{\text {opt }} \cdot \gamma_{\text {opt }}\right) \text { MAPE }\end{array}$} \\
\hline & RMSE & MAPE & TS & RMSE & MAPE & TS & RMSE & MAPE & TS \\
\hline $\mathbf{A}$ & 3018.5 & $32.5 \%$ & -9.8 & 2760.4 & $28.1 \%$ & -0.6 & 2760.4 & $28.1 \%$ & -0.6 \\
\hline $\mathbf{B}_{1}$ & 2509.1 & $40.4 \%$ & -6.2 & 2397.4 & $37.4 \%$ & -0.4 & 2397.4 & $37.4 \%$ & -0.4 \\
\hline $\mathbf{B}_{2}$ & 380.8 & $26 \%$ & 3.7 & 379 & $25.7 \%$ & 4.9 & 402.6 & $24.7 \%$ & 13.5 \\
\hline $\mathbf{B}_{3}$ & 478.9 & $33.3 \%$ & 2.8 & 474.5 & $32.1 \%$ & 5.3 & 532.9 & $29.4 \%$ & 16.8 \\
\hline $\mathbf{B}_{4}$ & 480.4 & $31.5 \%$ & 4.7 & 473 & $30.5 \%$ & 8.5 & 473 & $30.5 \%$ & 8.3 \\
\hline $\mathrm{B}_{5}$ & 1379.5 & $52.2 \%$ & -0.04 & 1326.3 & $46.17 \%$ & 5.3 & 1338.6 & $43.6 \%$ & 8.4 \\
\hline$\Sigma \mathrm{B}$ & 4774.3 & $37.7 \%$ & -17.8 & 3135.6 & $20.43 \%$ & -1.1 & 3135.6 & $20.4 \%$ & -1.1 \\
\hline $\mathrm{C}$ & 427.8 & $31.4 \%$ & 4.4 & 425.9 & $31.26 \%$ & 4.7 & 471.1 & $29.1 \%$ & 15.1 \\
\hline D & 265 & $35.6 \%$ & 4.5 & 263.4 & $35.17 \%$ & 5.4 & 283 & $33.5 \%$ & 14.6 \\
\hline $\mathbf{E}$ & 469.5 & $36.8 \%$ & 3.6 & 465.7 & $36.23 \%$ & 4.8 & 499.5 & $34.9 \%$ & 13.3 \\
\hline $\mathbf{F}$ & 399.8 & $34.7 \%$ & 4.6 & 394.4 & $33.61 \%$ & 7.3 & 395.9 & $33.1 \%$ & 9.7 \\
\hline
\end{tabular}

Table 7. The best forecasting methods for comparing product error function

\begin{tabular}{|c|c|c|c|}
\hline Prod. & RMSE & MAPE & TS \\
\hline A & W. Mov. Average 3 opt RMSE & $\begin{array}{l}\text { W. Mov. Average } 4 \text { opt MAPE } \\
\text { W. Mov. Average } 6 \text { opt MAPE }\end{array}$ & W. Mov. Average 6 opt MAPE \\
\hline $\mathbf{B}_{1}$ & W. Mov. Average 6 opt RMSE & Holt's method $\left(\alpha_{\text {opt }} \cdot \beta_{\text {opt }}\right)$ MAPE & W. Mov. Average 2 opt RMSE \\
\hline $\mathbf{B}_{2}$ & W. Mov. Average 3 opt RMSE & $\begin{array}{l}\text { Winter's method }\left(\alpha_{\text {opt }} \cdot \beta_{\text {opt }} \cdot \gamma_{\text {opt }}\right) \\
\text { MAPE }\end{array}$ & Last period estimation \\
\hline $\mathbf{B}_{3}$ & W. Mov. Average 6 opt RMSE & W. Mov. Average 4 opt MAPE & Last period estimation \\
\hline $\mathbf{B}_{4}$ & W. Mov. Average 3 opt RMSE & Holt's method $\left(\alpha_{\text {opt }} \cdot \beta_{\text {opt }}\right)$ MAPE & Moving average 2 \\
\hline $\mathbf{B}_{5}$ & W. Mov. Average 6 opt RMSE & $\begin{array}{l}\text { Winter's method }\left(\alpha_{\text {opt }} \cdot \beta_{\text {opt }} \cdot \gamma_{\text {opt }}\right) \\
\text { MAPE }\end{array}$ & $\begin{array}{c}\text { Winter's method }(\alpha . \beta . \gamma) \\
=(0.01 ; 0.01 ; 0.9)\end{array}$ \\
\hline$\Sigma \mathbf{B}$ & W. Mov. Average 6 opt RMSE & Holt's method $\left(\alpha_{\text {opt }} \cdot \beta_{\text {opt }}\right)$ MAPE & W. Mov. Average 6 opt RMSE \\
\hline $\mathrm{C}$ & W. Mov. Average 6 opt RMSE & W. Mov. Average 6 opt MAPE & Last period estimation \\
\hline D & W. Mov. Average 6 opt RMSE & W. Mov. Average 4 opt MAPE & W. Mov. Average 2 opt MAPE \\
\hline $\mathbf{E}$ & W. Mov. Average 6 opt RMSE & W. Mov. Average 4 opt MAPE & Last period estimation \\
\hline $\mathbf{F}$ & All average & $\begin{array}{l}\text { Exponential smoothing } \alpha_{\text {opt }} \text { MAPE } \\
\text { Holt's method }\left(\alpha_{\text {opt }} \cdot \beta_{\text {opt }}\right) \text { MAPE }\end{array}$ & Last period estimation \\
\hline
\end{tabular}

After all, each of the mentioned forecast methods gives good results for sales forecasting of some products, while for the others results are not very good.

Table 7 presents the aggregate results of simulation for different products and different error functions. The following forecasting methods, which compare each other, gave the best results in terms of minimum error functions:

- Three months weighted moving average optimized for RMSE (products: A, $\left.\mathrm{B}_{2}, \mathrm{~B}_{4}\right)$; Six months weighted moving average optimized for RMSE (products: $\mathrm{B}_{1}$,
$\mathrm{B}_{3}, \mathrm{~B}_{5}$, Sum of B, C, D, E); All average for RMSE (product F);

- Four months weighted moving average optimized for MAPE (products: A, $\left.\mathrm{B}_{3}, \mathrm{D}, \mathrm{E}\right)$; Six months weighted moving average optimized for MAPE (products: A, C); Holt's method, $\alpha_{\text {opt }}, \beta_{\text {opt }}$ for MAPE (products: $\mathrm{B}_{1}, \mathrm{~B}_{4}$, Sum of B, F); Winter's method, $\alpha_{\text {opt }}, \beta_{\text {opt }}, \gamma_{\text {opt }}$ for MAPE, (products: $\left.\mathrm{B}_{3}, \mathrm{~B}_{5}\right)$; Exponential smoothing $\alpha_{\mathrm{opt}}$ for MAPE, (product: F);

- The same analysis was done for tracking signal (TS), as shown in Table 7. 
Each forecasting method is intended for a specific forecasting case and is under a strong influence of criteria function chosen by a decision maker, i.e. manager. However, if a manager does not have enough experience, he/she can "play" through the focus forecasting system with a group of forecasting methods and a group of forecasting accuracy indicators and functions to come to a better decision.

\section{CONCLUSION}

The paper presents the research of a real forecasting sales problem in a FMCG supply chain. The aim was not to explore whether one sales forecasting method is better that the other, but to present the focus forecasting methodology and describe the possibility of managers' decision support in forecasting sales.

We analysed a real business practice problem of forecasting sales of two different types of products, using the following sales forecasting methods: Last period estimation, all average, moving average, weighted moving average, exponential smoothing, Holt's model and Winter's model. The evaluation of forecasting success was done by the following forecasting error indicators: RMSE, MAPE and TS.

Obtained results in focus forecasting analysis have showed that there is not one sales forecasting method which gave the best results of forecasting (i.e. smallest forecasting error) for all observed products. Different methods give different results that depend on the past sales of products and the way managers observe the forecasting accuracy. So, it is necessary that forecasting techniques are being monitored and evaluated continuously. Now days, it is possible by using modern information systems like business intelligence and business analytics systems. This case study also indicates the need for it.

The limitation of this paper is reflected in using specific type of FMCG supply chain, where one exclusive distributor control the whole supply chain and collect the information about retail sales. That case is much easier for implementing successful forecasting system in supply chain system than in systems with lot of distributors. Limitation of this paper and presented focus forecasting system is also reflected in the following: We use short range of FMCG (two type cereals for breakfast and cereals bars), who may had specific characteristics that influences sales in compared maybe some to another type of FMCG. We didn't use information about phases of product life cycle, which can have an impact on moving sales of one product. The sales of products that are being forecasted in this analysis are the basic ones without any assumptions of marketing activity influences that may have induced strong and rapid sales fluctuations in supply chain.

The implications of this research should point out to new possibilities for upgrading enterprise forecasting systems, especially in enterprises that are in a supply chain with FMCG. Further research on this topic can include more time-series forecasting methods and methods that are in a group of associative methods. The overall purpose is a continuous improvement of enterprise performances. 


\section{List of abbreviations:}

FMCG - Fast moving consumer goods;

SCM - Supply Chain Management;

$\mathbf{F I T}_{\mathbf{t}}-$ exponential smoothing forecast that includes trends in period $\mathrm{t}$;

FITS $_{\mathbf{t}}$ - exponential smoothing forecast that includes trend and seasonality in period t;

MAD - Mean Absolute Deviation;

MAPE - Mean Absolute Percentage Error;

MSE - Mean Squared Error;

RMSE - Root Mean Square Error;

TS - Tracking Signal;

CFE - Cumulated Forecast Error;

Products A to E - five different types of breakfast cereals

Product $\mathbf{B}_{1}$ to $\mathbf{B}_{5}$ - five different variants of breakfast cereals taste (for example: chocolates, almonds, honey...);

$\Sigma \mathbf{B}-$ sales sum of all five variants of product $\mathrm{B}_{1}$ to $\mathrm{B}_{5}$

Product F - cereal bar snacks. 


\title{
ФОКУСНО ПРЕДВИЪАЫЕ У ЛАНЦУ СНАБДЕВАЊА: СТУДИЈА СЛУЧАЈА КОМПАНИЈЕ СА РОБОМ ШИРОКЕ ПОТРОШЫЕ У СРБИЈИ
}

\author{
Зоран Ракићевић, Мирко Вујошевић
}

\begin{abstract}
Извод
Овај рад представља примену фокусног предвићања у ланцу снабдевања робе широке потрошње. Фокусно предвиђање је тестирано на стварном примеру из пословања једног предузећа у Србији. Подаци који су коришћени у симулацији односе се на историјске податке о продаји две групе робе широке потрошње са неколико различитих производа. Подаци о овим производима су прикупљени и сумирани кроз читав дистрибутивни канал на тржишту Србије у периоду од јануара 2012. до децембра 2013. године. На подацима о продаји је примењено неколико познатих метода за предвиђање временских серија, коришћењем приступа фокусног предвиђања. Приступ фокусног предвиђања комбинује различите методе предвиђања на временској серији података у циљу проналажења методе која је била најпрецизнија у предвиђању протеклих периода, за предвиђање у будућем периоду. Тачност предвиђања је дефинисана помоћу неколико индикатора којима се мере грешке предвиђања. У овом раду, уз помоћ "Microsoft Excel-a", имплементиране су следеће методе предвиђања продаје: предвиђање по последњем периоду продаје, просек продаје из свих претходних временских периода, покретни просек, експоненцијално изравнање са константним и варијабилним параметром $\alpha$, експоненцијално изравнање са укљученим трендом, експоненцијално изравнање са укљученим трендом и сезоналношћу. Основна сврха у раду није била евалуација различитих метода предвиђања, већ приказ практичне примене фокусног предвиђања на реалном пословном примеру.
\end{abstract}

Кључне речи: фокусно предвиђање, покретни просек, експоненцијално изравнање, "Нolt"-ов модел, "Winter"“-ов модел, роба широке потрошње

\section{References}

Bratu-Simionescu, M. (2013). Improvements in assessing the forecasts accuracy: A case study for Romanian macroeconomic forecasts. Serbian Journal of Management, 8 (1), 53-65.

Chang, P.C., \& Lin, Y.K. (2010). New challenges and opportunities in flexible and robust supply chain forecasting systems Editorial. International Journal of Production Economics, 128 (2), 453-456.

Chen, A., \& Blue, J. (2010). Performance analysis of demand planning approaches for aggregating, forecasting and disaggregating interrelated demands. International Journal of Production Economics, 128 (2), 586-602.

Chopra, S., \& Meindl, P. (2007). Supply chain management. Strategy, planning \& operation. New Jersey: Pearson, Prentice Hall.

Davydenko, A., \& Fildes, R. (2013). Measuring forecasting accuracy: The case of judgmental adjustments to SKU-level demand forecasts. International Journal of Forecasting, 29 (3), 510-522.

Ferbar, L., Čreslovnik, D., Mojškerc, B., \& Rajgelj, M. (2009). Demand forecasting 
methods in a supply chain: Smoothing and of a soft drink company in the UK. denoising. International Journal of International Journal of Production Production Economics, 118 (1), 49-54.

Fildes, R., Goodwin, P., Lawrence, M., \& Nikolopoulos, K. (2009). Effective forecasting and judgmental adjustments: an empirical evaluation and strategies for improvement in supply-chain planning. International Journal of Forecasting, 25 (1), 3-23.

Gardner Jr, E.S., Anderson-Fletcher, E.A., \& Wicks, A.M. (2001). Further results on focus forecasting vs. exponential smoothing. International Journal of Forecasting, 17 (2), 287-293.

Heizer, J., \& Render, B. (2011). Operations Management. New Jersey: Prentice Hall.

Huang, T., Fildes, R., \& Soopramanien, D. (2014). The value of competitive information in forecasting FMCG retail product sales and the variable selection problem. European Journal of Operational Research, 237 (2), 738-748.

Kerkkänen, A., Korpela, J., \& Huiskonen, J. (2009). Demand forecasting errors in industrial context: Measurement and impacts. International Journal of Production Economics, 118 (1), 43-48.

Min, H., \& Yu, W.B.V. (2008). Collaborative planning, forecasting and replenishment: demand planning in supply chain management. International Journal of Information Technology and Management, 7 (1), 4-20.

Oyatoye, E.O., \& Fabson, T.V.O. (2011). A comparative study of simulation and time series model in quantifying bullwhip effect in supply chain. Serbian Journal of Management, 6 (2), 145-154.

Ramanathan, U., \& Muyldermans, L. (2010). Identifying demand factors for promotional planning and forecasting: A case

Sayed, H.E., Gabbar, H.A., \& Miyazaki, S. (2009). A hybrid statistical genetic-based demand forecasting expert system. Expert Systems with Applications, 36 (9), 1166211670.

Thomassey, S. (2010). Sales forecasts in clothing industry: the key success factor of the supply chain management. International Journal of Production Economics, 128 (2), 470-483.

Yang, B., \& Burns, N. (2003). Implications of postponement for the supply chain. International Journal of Production Research, 41 (9), 2075-2090.

Vayvay, O., Dogan, O., \& Ozel, S. (2012). Forecasting techniques in fast moving consumer goods supply chain: a model proposal. International Journal of Information Technology and Business Management, 13 (1), 118-128.

Vujošević, M. (1997). Operational management: quantitative methods. Yugoslav Operational Research Society DOPIS, Belgrade. (in Serbian)

Warren Liao, T., \& Chang, P.C. (2010). Impacts of forecast, inventory policy, and lead time on supply chain inventory - a numerical study. International Journal of Production Economics, 128 (2), 527-537.

Wallström, P., \& Segerstedt, A. (2010). Evaluation of forecasting error measurements and techniques for intermittent demand. International Journal of Production Economics, 128 (2), 625-636.

Zamarripa, M.A., Aguirre, A.M., Méndez, C.A., \& Espuña, A. (2012). Improving supply chain planning in a competitive environment. Computers \& Chemical Engineering, 42, 178-188. 